\title{
Effect of dietary supplementation with omega-3 and -6 on fresh and frozen/thawed sperm quality of dogs
}

\author{
Efeito da suplementação na dieta com ômega-3 e -6 sobre a \\ qualidade do sêmen fresco e congelado de cães
}

\author{
Ana Carolina Rodrigues ${ }^{1}$; Camila Montanari Ruiz²; Carla Daniela Dan De Nardo ${ }^{3}$; \\ Gabriele Barros Mothé4; Fabiano Martinez Rossi ${ }^{5}$; Daniel Bartoli de Sousa ${ }^{6}$; \\ Halim Atique $\mathrm{Netto}^{7}$; Fabiana Ferreira de Souza ${ }^{8 *}$
}

\begin{abstract}
For years, fatty acids have been recommended as a dietary supplement to improve canine hair. For animal reproduction, supplementation with omegas has been used to increase the reproductive efficiency and conception rate, but few studies have been conducted in dogs. The aim of this study was to evaluate the effects of daily dietary supplementation with omega- 3 and -6 on the quality of fresh and frozen/ thawed semen in canines. Semen was collected from seven dogs and evaluated for sperm motility, vigor, concentration, and morphology. The 17-week study included 119 ejaculates and was divided according to oral supplementation with omega-3 and -6 : M1 $\left(1^{\text {st }}-5^{\text {th }}\right.$ week $)$ or pre-supplementation; M2 ( $6^{\text {th }}-9^{\text {th }}$ week $)$ and M3 ( $10^{\text {th }}-13^{\text {th }}$ week $)$ or during supplementation; and M4 (14 ${ }^{\text {th }}-17^{\text {th }}$ week $)$ or postsupplementation. After analysis, the semen was frozen and then revaluated both immediately and 30 minutes $\left(\right.$ at $\left.37^{\circ} \mathrm{C}\right)$ after thawing. Supplementation with omegas increased sperm motility, vigor, and concentration; however, supplementation had no influence on semen freezability. In addition, there was no improvement in sperm motility after supplementation when the thawed cells were maintained at $37^{\circ}$ $\mathrm{C}$ for 30 minutes. We concluded that dietary supplementation with omega- 3 and -6 for 4 to 8 weeks can improve the quality of fresh semen, although it has no effect on the freezability of canine semen.

Key words: Canine. Diet-supplemented. Polyunsaturated-fatty-acid. Sperm.
\end{abstract}

\section{Resumo}

Os ácidos graxos têm sido recomendados há anos como suplemento dietético para a melhora do pelo canino. $\mathrm{Na}$ área de reprodução animal, a suplementação com ômega tem sido usada para aumentar a eficiência reprodutiva e a taxa de concepção em muitas espécies, mas poucos estudos foram conduzidos em cães. Então, o objetivo deste estudo foi avaliar os efeitos da suplementação dietética diária com ômega-3 e -6 sobre a qualidade do sêmen fresco e congelado de cães. Os ejaculados foram colhidos

\footnotetext{
${ }^{1}$ Médica Veterinária Clínica Veterinária São Lázaro, São José do Rio Preto, SP, Brasil. E-mail: cvsaolazaro@terra.com.br

2 Médica Veterinária, Laboratório de Patologia Veterinária, VETPAT, Campinas, SP, Brasil. E-mail: camilamontanari@yahoo.com.br

${ }^{3}$ Prof $^{\mathrm{a}}$ Dr $^{\mathrm{a}}$, Centro Universitário de Rio Preto, UNIRP, São José do Rio Preto, SP, Brasil. E-mail: carladan@unirp.edu.br

${ }^{4}$ Discente de Doutorado, Programa de Clínica e Reprodução Animal da Universidade Federal Fluminense, UFF, Niterói, RJ, Brasil. E-mail: gabimothe2@hotmail.com

${ }^{5}$ Biólogo, Centro Universitário de Rio Preto, UNIRP, São José do Rio Preto, SP, Brasil. E-mail: fabianorossi.claro@gmail.com

${ }^{6}$ Prof. Dr., Universidade Federal de Goiás, UFG, Jataí, GO, Brasil. E-mail: dbsousa@uol.com.br

7 Prof. Dr., Centro Universitário de Rio Preto, UNIRP, São José do Rio Preto, SP, Brasil. E-mail: halimnetto@unirp.edu.br

${ }^{8}$ Pesquisadora III, Departamento de Reprodução Animal e Radiologia Veterinária, da Faculdade de Medicina Veterinária e Zootecnia, Universidade Estadual Paulista "Júlio de Mesquita Filho", UNESP, Botucatu, SP, Brasil. E-mail: fafesouza@fmvz. unesp.br

* Author for correspondence
} 
de 7 cães e avaliados quanto a motilidade espermática, vigor, concentração e morfologia. O estudo foi dividido de acordo com os períodos de suplementação oral com omegas-3 e -6 , no qual M1 ( $1^{\text {a }}$ $5^{\mathrm{a}}$ semana) foi considerado o período pré-suplementação, M2 (6 $6^{\mathrm{a}}-9^{\mathrm{a}}$ semana) e M3 (10 $0^{\mathrm{a}}-13^{\mathrm{a}}$ semana) período de suplementação e M4 (14 ${ }^{\mathrm{a}}-17^{\mathrm{a}}$ semana) pós-suplementação, totalizando 17 semanas de estudo (119 ejaculados). Após a análise, o sêmen foi congelado e reavaliado imediatamente e 30 minutos após a descongelação (mantidas a $37^{\circ} \mathrm{C}$ ). A suplementação resultou em aumento da motilidade espermática, vigor e concentração do sêmen fresco; no entanto, não houve influência na congelabilidade do sêmen. Além disso, não houve aumento da motilidade dos espermatozoides após a suplementação, quando as células descongeladas foram mantidas a $37^{\circ} \mathrm{C}$, durante 30 minutos. Concluiu-se que a suplementação dietética com omegas-3 e -6, durante 4 a 8 semanas melhora os parâmetros do sêmen fresco de cães, embora não há nenhum efeito sobre a qualidade espermática após a congelação.

Palavras-chave: Ácido-graxo-poli-insaturado. Canino. Dieta-suplementada. Espermatozoide.

\section{Introduction}

Fatty acids are naturally present both in the membranes of sperm cells and in seminal plasma (SWAIN; MILLER JR, 2000; ZANIBONI et al., 2006). Several studies have confirmed the influence of fatty acids on seminal characteristics in different species. Among these fatty acids, polyunsaturated omega-3 (docosahexaenoic acid - DHA and eicosapentaenoic acid) and omega-6 (linoleic acid) have been widely cited (ANDREAZZI et al., 2004; MITRE et al., 2004; ATTAMAN et al., 2012; ESMAEILI et al., 2012; SCHMID-LAUSIGK; AURICH, 2014).

Ingestion of diets containing polyunsaturated fatty acids results in increased fertility due to improved sperm parameters (motility, vigor, concentration, and seminal volume), as described for horses supplemented with flaxseed oil (SCHMID-LAUSIGK; AURICH, 2014), sheep with fish oil (ESMAEILI et al., 2012), pigs with shark oil (MITRE et al., 2004), rabbits with canola oil (ANDREAZZI et al., 2004) and roosters with canola, soybean or sunflower oil with vitamin E (RODENAS et al., 2005).

In the male reproductive tract, polyunsaturated fatty acids have different functions. In bovines, highquality semen was related to a higher composition of fatty acids in seminal plasma and intracellular compartments in the sperm (ARGOV et al., 2007). Moreover, these molecules are involved in the modulation of sperm capacitation (RETTERSTOL et al., 2001) and membrane fluidity (CONNOR et al., 1998).

The positive effects of polyunsaturated fatty acids in the diet also have been described in relation to the cooling (CASTELLANO et al., 2010; SCHMIDLAUSIGK; AURICH, 2014; STREZEZEK et al., 2004) and freezing of semen (ESMAEILI et al., 2012), although the absence of effects on sperm freezability has also been noted (CASTELLANO et al., 2010).

Despite increasing interest in using polyunsaturated fatty acids via dietary supplementation to increase semen quality of different species, only Rocha et al. (2009) described an improvement in the quality of fresh semen of dogs supplemented with omega-3, -6 , and -9 and vitamin E. Thus, the objective of this study was to evaluate the influence of omega- 3 and -6 dietary supplementation on the quality of fresh and frozen/ thawed canine semen.

\section{Material and Methods}

Seven adult, mixed-breed dogs, each weighing approximately $15 \mathrm{~kg}$, were used. The dogs were housed in individual concrete-floored, experimental kennels, fed twice daily with commercial food (Royal Canin Club Performance, Premium Quality, Descalvado, SP, Brazil) and watered ad libitum. The experimental period lasted 17 consecutive weeks, during which semen samples were collected once a 
week. In the first 8 weeks, the dogs were conditioned to semen collection, but the samples that were collected during this time were not evaluated or included in the study. After the conditioning period, semen samples were collected over a 5-week period (M1, $1^{\text {st }}-5^{\text {th }}$ week) to evaluate the fresh and frozen/ thawed semen from dogs without supplementation. Then, for 8 weeks $\left(\mathrm{M} 2,6^{\text {th }}-9^{\text {th }}\right.$ week and M3, $10^{\text {th }}$ $13^{\text {th }}$ week), the animals were supplemented orally each day with omega-3 (eicosapentaenoic acid and docosahexaenoic acid - DHA) and -6 (linoleic acid) (Vetnil Industry and Trade of Veterinary Products Ltda., Louveira, SP, Brazil, concentrations and dosages indicated for Pêlo \& Derme, but containing only the omegas, at concentration $39.97 \mathrm{mg}$ omega-3 and $283.40 \mathrm{mg}$ omega-6), administered to each $10 \mathrm{~kg}$ of body weight. After the supplementation period, semen was collected for an additional 4 weeks (M4, $14^{\text {th }}-17^{\text {th }}$ week), resulting in a total of 17 weeks of study.

Semen was collected by digital manipulation of the penis and evaluated for motility, sperm vigor, sperm concentration (x106/mL) and morphology. The semen volume was evaluated via collection in a graduated tube. Sperm motility and vigor were evaluated by placing a seminal drop on a pre-warmed $\left(\sim 38^{\circ} \mathrm{C}\right)$ slide and covering it with a coverslip. Sperm motility $(0-100 \%)$ was subjectively estimated in increments of $5 \%$ using a phase contrast microscope set to $100 \mathrm{X}$ magnification. Vigor was scored using a scale of $0-5$, where 0 indicates no movement and 5 indicates vigorous movement. Semen was diluted 1:20 in formol-saline and a Neubauer chamber was used to count spermatozoa under a phase contrast microscope set to $1,000 \mathrm{X}$ magnification. Semen smears were made, fixed in formol-saline at $37^{\circ} \mathrm{C}$ for $10 \mathrm{~min}$, and then stained by the modified Karras method (PAPA et al., 1986). For each ejaculate, 200 spermatozoa were observed using a microscope set to $1,000 \mathrm{X}$ magnification. Sperm morphology was classified as normal or as having a major or minor defect (BLOM, 1972).
After collection, the samples were evaluated and centrifuged at $800 \mathrm{xg}$ for 10 minutes. The supernatant was discarded and the pellet was diluted to a final concentration $80 \times 10^{6}$ mobile cells $\mathrm{mL}^{-1}$ in TRIS-glucose-egg yolk containing 7\% glycerol (MARTINS, 2005). The samples were packaged in $0.5-\mathrm{mL}$ French straws. The straws were cooled at $4^{\circ} \mathrm{C}$ for 1 hour and then frozen for 20 minutes using $6 \mathrm{~cm}$ of liquid nitrogen in a polystyrene box. Then, the straws were immersed in liquid nitrogen and stored in a cryogenic container at $-196^{\circ} \mathrm{C}$. The straws were thawed at $72^{\circ} \mathrm{C}$ for 8 seconds in a water bath (CHIRINÉA et al., 2006). The thawed samples were maintained at $37^{\circ} \mathrm{C}$ for 30 minutes and then immediately revaluated for motility and vigor.

The data were presented as the mean \pm standard error and analyzed using a Kruskal-Wallis one-way analysis of variance of ranks; multiple pairwise comparisons were performed using a BonferroniDunn test. The SigmaPlot for Windows software v.11.0 (2008) was used to perform the analyses. Differences were considered significant at $\mathrm{p} \leq 0.05$.

\section{Results}

Overall, 119 samples were evaluated during the experimental periods (M1 to M4), excluding the first 8 weeks of conditioning and collection.

The results of the analysis of fresh semen (Table 1) showed increased sperm motility and vigor during the first 4 weeks of supplementation (M2) with omegas, which persisted for 30 days after the end of treatment (M4). The sperm concentration was higher in the second treatment period (M3) and then declined to the pre-supplementation values after the end of treatment (M4). There was no variation in the percentage of morphologically normal cells between the periods of the study; however, the percentage of major and minor defects did vary between periods.

There was no difference between periods in frozen/thawed sperm motility and vigor. Supplementation also did not prevent the decrease of 
vigor and sperm motility after sperm were thawed. In the M1 group, sperm motility was not different between fresh and thawed semen, but there was a decrease in motility when the cells were maintained at $37^{\circ} \mathrm{C}$ for 30 minutes. The same results were observed for sperm vigor.

Table 1. Mean \pm standard error of seminal parameters of fresh and frozen/thawed semen of 7 dogs submitted to 4 treatments: pre-supplementation (M1), during the first 4 weeks (M2), during the subsequent 4 weeks (M3), and 4 weeks after dietary oral supplementation (M4) with omega-3 and -6 .

\begin{tabular}{|c|c|c|c|c|}
\hline Seminal Parameter & $\begin{array}{c}\text { M1 } \\
\left(1^{\text {st }-5^{\text {th }}} \text { week }\right)\end{array}$ & $\begin{array}{c}\mathrm{M} 2 \\
\left(6^{\text {th }}-9^{\text {th }} \text { week }\right)\end{array}$ & $\begin{array}{c}\text { M3 } \\
\left(10^{\text {th }}-13^{\text {th }} \text { week }\right)\end{array}$ & $\begin{array}{c}\mathrm{M} 4 \\
\left(14^{\text {th }}-17^{\text {th }} \text { week }\right)\end{array}$ \\
\hline Motility (0 a 100\%) & $74.7 \pm 4.1^{\mathrm{aA}}$ & $88.4 \pm 1.8^{\mathrm{bA}}$ & $89.3 \pm 2.2^{\mathrm{bA}}$ & $93.1 \pm 0.9^{\mathrm{bA}}$ \\
\hline Vigor (0 a 5) & $3.4 \pm 0.2^{\mathrm{aA}}$ & $4.4 \pm 0.1^{\mathrm{bA}}$ & $4.2 \pm 0.7^{\mathrm{bA}}$ & $4.6 \pm 0.1^{\mathrm{bA}}$ \\
\hline Concentration $\left(\mathrm{x} 10^{6} / \mathrm{mL}\right)$ & $312.0 \pm 60.4^{\mathrm{a}}$ & $362.2 \pm 57.7^{\mathrm{a}, \mathrm{b}}$ & $448.3 \pm 61.7^{\mathrm{b}}$ & $253.4 \pm 37.6^{\mathrm{a}}$ \\
\hline Normal Cells (\%) & $90.9 \pm 3.9$ & $94.6 \pm 0.8$ & $95.4 \pm 0.8$ & $95.2 \pm 0.6$ \\
\hline Major Defects (\%) & $2.0 \pm 0.4^{\mathrm{a}, \mathrm{b}}$ & $2.7 \pm 0.7^{\mathrm{a}, \mathrm{b}}$ & $1.8 \pm 0.4^{\mathrm{a}}$ & $3.4 \pm 0.6^{\mathrm{b}}$ \\
\hline Minor Defects (\%) & $1.3 \pm 0.4^{\mathrm{a}}$ & $2.8 \pm 0.5^{\mathrm{b}}$ & $2.6 \pm 0.6^{\mathrm{a}, \mathrm{b}}$ & $1.5 \pm 0.4^{\mathrm{a}}$ \\
\hline Post-thaw motility (\%) & $73.1 \pm 3.0^{\mathrm{A}}$ & $68.6 \pm 4.5^{\mathrm{B}}$ & $77.0 \pm 1.9^{\mathrm{B}}$ & $72.0 \pm 5.4^{\mathrm{B}}$ \\
\hline Post-thaw vigor $(0-5)$ & $3.5 \pm 0.1^{\mathrm{A}}$ & $3.1 \pm 0.2^{\mathrm{B}}$ & $3.6 \pm 0.1^{\mathrm{B}}$ & $3.3 \pm 0.2^{\mathrm{B}}$ \\
\hline $30^{\prime}$ post-thaw motility (\%) & $61.0 \pm 4.1^{\mathrm{B}}$ & $55.5 \pm 4.2^{\mathrm{C}}$ & $66.4 \pm 2.6^{\mathrm{C}}$ & $60.7 \pm 5.9^{\mathrm{C}}$ \\
\hline $30^{\prime}$ post-thaw vigor $(0-5)$ & $3.0 \pm 0.2^{\mathrm{A}}$ & $3.0 \pm 0.2^{\mathrm{B}}$ & $3.1 \pm 0.1^{\mathrm{C}}$ & $2.8 \pm 0.2^{\mathrm{B}}$ \\
\hline
\end{tabular}

Different lowercase letters in rows indicate significant differences between periods (M1, M2, M3 and M4) (p $\leq 0.05)$. Different uppercase letters in columns indicate significant differences for the same parameter before and after thawing (motility $v s$ post-thaw motility vs 30' post-thaw motility, and vigor $v s$ post-thaw vigor $v s 30$ ' post-thaw vigor $)(\mathrm{p} \leq 0.05)$.

\section{Discussion}

Polyunsaturated fatty acids are components of seminal plasma, are present in the membranes of sperm cells, and influence the fluidity of the membrane (CONNOR et al., 1998), motility (ZERON et al., 2002) and capacitation in sperm (RETTERSTOL et al., 2001). However, their use as a food supplement to increase semen quality or to treat testicular degeneration has not been fully elucidated in dogs, although it has been reported in other species (ANDREAZZI et al., 2004; MITRE et al., 2004; RODENAS et al., 2005; ATTAMAN et al., 2012; ESMAEILI et al., 2012; SCHMIDLAUSIGK; AURICH, 2014).

Omega-3 and -6 are essential components of the plasma membrane of spermatozoa and, when they are supplied through nutraceuticals, increase membrane stability, thus allowing spermatozoa to withstand the physical stress caused by cooling and freezing. However, the effects of omegas on the sperm quality of animals appear to be inconsistent.
These contradictions can be explained by the susceptibility of sperm membranes to oxidative damage. Lipid peroxidation decreases the integrity of cell membranes rich in polyunsaturated fatty acids, which increases permeability and makes it difficult to regulate the intracellular ionic concentrations. With decreased sperm motility, fertilization potential is also reduced. Therefore, supplementation with fatty acids should be combined with antioxidants to effectively improve the integrity of the sperm membrane (SCHMIDLAUSIGK; AURICH, 2014; FREITAS et al., 2016). Although we used a formulation that contained only omegas and observed higher-quality fresh sperm post-supplementation, there was no improvement in the results of the frozen/thawed samples.

The motility and vigor of sperm directly influence fertilizing capacity and the structural and functional competence of sperm cells, so these parameters are considered essential in the evaluation of semen quality (DOBRINSKY et al., 1993). In this study, 
there were increases in sperm motility and vigor in the first four weeks of treatment (M2) that persisted even after the end of supplementation (M4), which confirmed that the diet enriched with omega-3 and -6 increases the semen quality of dogs. This result agrees with those of Rocha et al. (2009), who showed a positive effect of dietary supplementation with omega-3, -6 and -9 and vitamin $E$ for 60 days on the quality of fresh semen of this species, as characterized by increased sperm motility, vigor, increased semen volume, and a reduction of abnormal sperm. Our result also agrees with those of Risso et al. (2016), who showed that in addition to increasing the serum concentration of testosterone, fish oil increased the quality of fresh semen in dogs via increases in sperm motility, total sperm counts, total sperm viability and normal morphology.

The effects observed in this study in dogs also agree with results observed in other species, including boars supplemented with shark oil (MITRE et al., 2004), sheep with fish oil (ESMAEILI et al., 2012) and roosters with oils containing a high concentration of polyunsaturated fatty acids in the diet, particularly when combined with vitamin $\mathrm{E}$ (RODENAS et al., 2005). For stallions, in addition to vitamin E, supplementation with L-carnitine and selenium in combination with omega-3 and -6 resulted in increased motility and integrity of the acrosome and plasma membranes of fresh and frozen/thawed semen (FREITAS et al. 2016). Additionally, the authors concluded that increased sperm motility is related to the use of antioxidants, while the improvement in membrane integrity was attributed mainly to the higher concentration of polyunsaturated fatty acids associated with antioxidants. Thus, in stallions, the isolated use of omegas did not result in large effects on sperm quality (FREITAS et al., 2016). These effects were attributed only to antioxidant supplementation (SCHMID-LAUSIGK; AURICH, 2014). In the case of bulls, supplementation with only omega-3s resulted in improvements in the total and progressive motility, mean velocity of the trajectory, and HOST- positive and proportion of fast spermatozoa in fresh semen, although there were no pronounced effects in frozen-thawed semen (GHOLAMI et al., 2010).

During the supplementation period, the sperm concentration of the studied dogs was higher, but it decreased after the end of treatment (M4) to the pre-supplementation values. In contrast, in pigs that received supplementation, there was an increase in sperm concentration starting in the 8th week of treatment, which was explained by the time required to complete spermatogenesis until sperm maturation in this species (ESTIENNE et al., 2008). In addition, in rabbits fed a diet containing canola oil, which is rich in omega-3, an increased sperm concentration, higher semen volume and increased total sperm quantity were all reported (ANDREAZZI et al., 2004).

One of the mechanisms that explains the action of fatty acids is the inhibitory effect of omega-3 (eicosapentaenoic acid) on prostaglandin biosynthesis via competition for cyclooxygenase-2 enzyme sites (CULP et al., 1979); this contributes to the reduction of mediators of inflammation, in turn reducing cell injury and improving sperm quality (ROCHA et al., 2009).

In dogs, infertility can be related to the percentage of sperm defects, so $80 \%$ or more of the sperm in the ejaculate should be without morphological defects (OETTLÉ, 1993; ROOT; JOHNSTON, 1994). Although the percentage of major or minor defects varied in some periods of our study, the morphology of the sperm cells of dogs remained within the normal limits for the species (ROOT; JOHNSTON, 1994), demonstrating that supplementation with omega-3 and -6 did not affect sperm morphology. In contrast, in humans who ingested a diet supplemented with omega-3, there was a decrease in sperm defects, and the intake of saturated fats negatively influenced the concentration of sperm (ATTAMAN et al., 2012).

Supplementation with omega-3 and -6 had no effect on the freezability of semen, which was also mentioned by Castellano et al. (2010) in pigs. 
The absence of positive effects on the freezability of sperm in this study was unexpected because supplementation with omega-3 increases the antioxidant activity of seminal fluid, which prevents the oxidation of macromolecules (DNA, proteins and lipids) (MAZZA et al., 2007), allows the greater protection of sperm membranes via the inhibited lipid peroxidation, and ultimately contributes to a higher quality of semen and, in particular, increased motility after thawing (AURICH et al., 1997; MICHAEL et al., 2009; MOURVAKI et al., 2010). However, Esmaeili et al. (2012) observed superior sperm parameters in ovine semen after thawing. Strezezek et al. (2004) observed a positive influence of treatment on sperm parameters (motility, percentage of live sperm, membrane integrity, and osmotic resistance of acrosomal membranes) of boars when the semen was cooled to $5^{\circ}$ or $16^{\circ} \mathrm{C}$. Further, in horses, dietary supplementation with flax seed oil combined with antioxidants attenuated a decline in motility and maintained the integrity of the sperm membrane of chilled semen during the winter, which allowed higher rates of fertility during this period (SCHMID-LAUSIGK; AURICH, 2014).

Based on our knowledge, this study provides the first evaluation of the effects of dietary supplementation with omega- 3 and -6 on frozen/ thawed sperm quality. We concluded that dietary supplementation with omega-3 and -6 for 4 weeks enhances the semen parameters of dogs and may increase the fresh sperm quality in this species but that there is no effect on semen freezability.

\section{Acknowledgements}

We thank the UNIRP for financial support to develop this research and Vetnil Industry and Trade of Veterinary Products Ltda (Louveira, SP, Brazil) for provide the omegas' formulation.

\section{Ethics Committee}

This study was conducted in accordance with the ethical guidelines recommended by the National Council for Control of Animal Experimentation and College of Animal Experimentation and was approved by the Institution's Animal Care and Experimentation Ethics Committee from Faculdade de Medicina Veterinária e Zootecnia, of Universidade Estadual Paulista "Júlio de Mesquita Filho”, UNESP, Botucatu, SP, Brazil.

\section{References}

ANDREAZZI, M. A.; SCAPINELLO, C.; MORAES, G. V.; FARIA, H. G.; MICHELAN, A. C.; GEORG, P. C. Avaliação da qualidade do sêmen em coelhos alimentados com rações contendo diferentes fontes de óleos vegetais. Acta Scientiarum - Animal Sciences, Maringá, v. 26, n. 1, p. 87-93, 2004.

ARGOV, N.; SKLAN, D.; ZERON, Y.; ROTH, Z. Association between seasonal changes in fatty-acid composition, expression of VLDL receptor and bovine sperm quality. Theriogenology, New York, v. 67, n. 4, p. 878-885, 2007.

ATTAMAN, J. A.; TOTH, T. L.; FURTADO, J.; CAMPOS, H.; HAUSER, R.; CHAVARRO, J. E. Dietary fat and semen quality among men attending a fertility clinic. Human Reproduction, Oxford, v. 27, n. 5, p. 14661474, 2012.

AURICH, J. E.; SCHONHERR, U.; HOPPE, H.; AURICH, C. Effects of antioxidants on motility and membrane integrity of chilled stored stallion semen. Theriogenology, New York, v. 48, n. 2, p. 185-192, 1997.

BLOM, E. The ultrastructure of some characteristic sperm defects and a proposal for a new classification of the bull spermiogram. In: SIMPOSIO INTERNATIOTIONALE DI ZOOTECNIA, 7., 1972, Milano. Proceedings... Milano: Società Italiana per il Progresso dela Zootecnia, 1972. p. 125-139.

CASTELLANO, C. A.; AUDET, I.; BAILEY, J. L.; LAFOREST, J. P.; MATTE, J. J. Dietary omega-3 fatty acids (fish oils) have limited effects on boar semen stored at $17{ }^{\circ} \mathrm{C}$ or cryopreserved. Theriogenology, New York, v. 74, n. 8, p. 1482-1490, 2010. 
CHIRINÉA, V. H.; MARTINS, M. I. M.; SOUZA, F. F.; TEBET, J. M.; PAPA, F. O.; LOPES, M. D. Características morfofuncionais do sêmen canino refrigerado e congelado, usando dois diferentes meios diluentes. Ciência Animal Brasileira, Goiânia, v. 7, n. 4, p. 407-415, 2006.

CONNOR, W. E.; LIN, D. S.; WOLF, D. P.; ALEXANDER, M. Uneven distribution of desmosterol and docosahexaenoic acid in the heads and tails of monkey sperm. The Journal of Lipid Research, San Diego, v. 39, n. 7, p. 1404-1411, 1998.

CULP, B. R.; TITUS, B. G.; LANDS, W. E. Inibition of prostaglandin biosynthesis by eicosapentaenoic acid. Prostaglandins and Medicine, New York, v. 3, n. 5, p. 269-278, 1979.

DOBRINSKY, I.; LULAI, C.; BARTH, A. D.; POST, $\mathrm{K}$. Effects of four different extenders and three different freezing rates on post-thaw viability of dog semen. Journal of Reproduction and Fertility, Oxford, v. 47, p. 291-296, 1993.

ESMAEILI, V.; SHAHVERDI, A. H.; ALIZADEH, A. R.; ALIPOUR, H.; CHEHRAZI, M. Saturated, omega- 6 and omega-3 dietary fatty acid effects on the characteristics of fresh, frozen-thawed semen and blood parameters in rams. Andrologia, Berlin, v. 46, n. 1, p. 4249, 2012.

ESTIENNE, M. J.; HARPER, A. F.; CRAWFORD, R. J. Dietary supplementation with a source of omega-3 fatty acids increases sperm number and the duration of ejaculation in boars. Theriogenology, New York, v. 70, n. 1, p. 70-76, 2008.

FREITAS, M. L.; BOUÉRES, C. S.; PIGNATARO, T. A.; OLIVEIRA, F. J. G.; VIU, M. A. O.; OLIVEIRA, R. A. Quality of fresh, cooled and frozen semen from stallions supplemented with antioxidants and fatty acids. Journal of Equine Veterinary Science, New York, v. 46, p. 1-6, 2016.

GHOLAMI, H.; CHAMANI, M.; TOWHIDI, A.; FAZELI, M. H. Effect of feeding a docosahexaenoic acid-enriched nutriceutical on the quality of fresh and frozen-thawed semen in Holstein bulls. Theriogenology, New York, v. 74, n. 9, p. 1548-1558, 2010.

MAZZA, M.; POMPONI, M.; JANIRI, L.; BRIA, P.; MAZZA, S. Omega- 3 fatty acids and antioxidants in neurological and psychiatric diseases: an overview. Progress in Neuro-Psychopharmacology and Biological Psychiatry, Oxford, v. 31, n. 1, p. 12-26, 2007.

MARTINS, M. I. M. Efeito da sazonalidade sobre a função testicular de cães. 2005. Tese (Doutorado em Medicina Veterinária) - Faculdade de Medicina
Veterinária e Zootecnia. Universidade Estadual Paulista Júlio de Mesquita Filho, Botucatu.

MICHAEL, A. J.; ALEXOPOULOS, C.; PONTIKI, E. A.; HADJIPAVLOU-LITINA, D. J.; SARATSIS, P.; VERVERIDIS, H. N.; BOSCOS, C. M. Effect of antioxidant supplementation in semen extenders on semen quality and reactive oxygen species of chilled canine spermatozoa. Animal Reproduction Science, Amsterdan, v. 112, n. 1-2, p. 119-135, 2009.

MITRE, R.; CHEMINADE, C.; ALLAUME, P.; LEGRAND, P.; LEGRAND, A. B. Oral intake of shark liver oil modifies lipid composition and improves motility and velocity of boar sperm. Theriogenology, New York, v. 62 , n. 8, p. 1557-1566, 2004.

MOURVAKI, E.; CARDINALI, R.; DAL BOSCO, A.; CORAZZI, L.; CASTELLINI, C. Effects of flaxseed dietary supplementation on sperm quality and on lipid composition of sperm subfractions and prostatic granules in rabbit. Theriogenology, New York, v. 73, n. 5, p. 629637,2010 .

OETTLÉ, E. E. Sperm morphology and fertility in the dog. Journal of Reproduction and Fertility, Oxford, v. 47, p. 257-260, 1993.

PAPA, F. O.; ALVARENGA, M.A.; CARVALHO, I. M.; BICUDO, S. D.; RAMIRES, P. R. N.; LOPES, M. D. Coloração espermática segundo KARRAS (1950), modificada pelo emprego de (Stryphinodendrum barbatimam). Arquivo Brasileiro de Medicina Veterinária e Zootecnia, Belo Horizonte, v. 40, p. 115-123, 1986.

RETTERSTOL, K.; HAUGEN, T. B.; TRAN, T. N.; CHRISTOPHERSEN, B. O. Studies on the metabolism of essential fatty acids in isolated human testicular cells. Reproduction, Cambridge, v. 121, n. 6, p. 881-887, 2001.

RISSO, A.; PELLEGRINO, F. J.; RELLING, A. E.; CORRADA, Y. Effect of long-term fish oil supplementation on semen quality and serum testosterone concentrations in males dogs. International Journal of Fertility and Sterility, Tehran, v. 10, n. 2, p. 223-231, 2016.

ROCHA, A. A.; CUNHA, I. C. N.; EDERLI, B. B.; ALBERNAZ, A. P.; QUIRINO, C. R. Effect of daily food supplementation with essential fatty acids on canine semen quality. Reproduction in Domestic Animals, Berlin, v. 44, p. 313-315, 2009. Supplement 2.

RODENAS, C. E. O.; MURGAS, L. D. S.; MACIEL, M. P.; FERRAZ, J. M.; RIBEIRO, M. C.; BERTECHINI, A. G.; FREITAS, R. T. F.; FIALHO, E. T. Características seminais de galos alimentados com rações suplementadas com diferentes óleos e níveis de vitamina E. Ciência e Agrotecnologia, Lavras, v. 29, n. 1, p. 160-167, 2005. 
ROOT, M. V.; JOHNSTON, S. D. Basics for complete reproductive examination of the male dog. Seminars in Veterinary Medicine and Surgery Small Animal, Philadelphia, v. 9, n. 1, p. 41-45, 1994.

SCHMID-LAUSIGK, Y. A.; AURICH, C. Influences of a diet supplemented with linseed oil and antioxidants on quality of equine semen after cooling and cryopreservation during winter. Theriogenology, New York, v. 81, n. 7, p. 966-973, 2014.

STREZEZEK, J.; FRASER, L.; KUKLINSKA, M.; DZIEKONSKA, A. Effect of dietary supplementation with polyunsaturated fatty acids and antioxidants on biochemical characteristics of boar semen. Reproductive Biology, Olsztyn, v. 4, n. 3, p. 271-287, 2004.
SWAIN, J. E.; MILLER JUNIOR, R. R. Technical report. A postcryogenic comparison of membrane fatty acids of elephant spermatozoa. Zoo Biology, New York, v. 19, n. 5, p. 461-473, 2000.

ZANIBONI, L.; RIZZI, R.; CEROLINI, S. Combined effect of DHA and a-tocopherol enrichment on sperm quality and fertility in the turkey. Theriogenology, New York, v. 65, n. 9, p. 1813-1827, 2006.

ZERON, Y.; TOMCZAK, M.; CROWE, J.; ARAV, A. The effect of liposomes on thermotropic membrane phase transitions of bovine spermatozoa and oocytes: implications for reducing chilling sensitivity. Cryobiology, New York, v. 45, n. 2, p. 143-152, 2002. 